\title{
The message of WYD liturgy Krakow 2016
}

Liturgical celebrations at World Youth Day have an essentially constant structure. They have developed gradually and each stage is a precious moment in the encounter of a young person with Christ in the Church today. ${ }^{1}$ Undoubtedly, a further value for young people is that they know the order of the celebrations and can expect what will be the center of their spiritual experience on a given day. The main WYD liturgical events and their message will be discussed here; however, the true way of a pilgrim during these Days begins much earlier and still continues after the official sending forth. Despite the established structure of the liturgical celebrations, each edition of WYD has its own characteristics, specified by its theme. It is always defined by the Holy Father, and on that basis, a logo, a hymn and texts for liturgical celebrations are selected.

Liturgy, by its nature, is the moment of a person's encounter with God who saves by the work of Jesus Christ and the descent of the Holy

1 This structure was controlled, up until 2016, by the section for Youth of the Pontifical Council for the Laity, and at the present (since 2016) a team working on the preparation of the next WYD entered into structure of the Pontifical Dicastery for the Laity the Family and Life. 
214 Spirit. ${ }^{2}$ However, it cannot be treated as means of popularizing any idea. Undoubtedly, it also has a didactic dimension, but it involves understanding and communicating the truth about God who reveals Himself to us in a celebration. ${ }^{3}$ Here we learn what God speaks to us, and so we cannot use the sacred rite for purposes which we designate ourselves.

Therefore, preparations for WYD celebrations had to take into account the noted principles of the Church. The main theme of this youth meeting, "Blessed are the merciful, for they shall obtain mercy," was to inspire a way of looking at the Savior and a dialogue with him. The liturgy should be shaped in such a way that the participant can hear His voice. This was emphasized by John Paul II when the structures of this event were being formed. He repeated that it was not about doing something for youth, as often happens in the other social systems, but that the Church should, together with the young and in their presence, discover the presence of the only Redeemer of man. Hence, the presence of the whole Church, also of the elderly, is necessary in these events, so that, together with the youth, they may discover Christ, who is Truth and Love. ${ }^{4}$

\section{The main liturgical celebrations}

The main WYD celebrations are the Opening Mass, the Papal Welcome with the short Liturgy of the Word, the Way of the Cross on Friday, the Vigil on Saturday evening, and the Sunday Closing Mass. In some ways, Confession should be included in these sacred celebrations, although it is held privately in numerous confessionals, which are now an intrinsic part of this great event. One can also mention the catecheses which take place in many locations, and which essentially always end with a liturgical celebration. However, here we will concentrate mainly on the five celebrations previously mentioned.

2 Cfr. Conc. Vatican II, Constitution Sacrosanctum Concilium (4 December 1963), 2.

3 Conc. Vatican II, Constitution Sacrosanctum Concilium (4 December 1963), 33.

4 Pope John Paul II, Address to Roman Curia (20 December 1985) 3, "Acta Apostolicae Sedis" 78 (1986), p. 623. 
The World Youth Day is usually opened by the bishop of the place where the event takes place. The local church, with its bishop, opens its arms to welcome multitudes of pilgrims coming from all over the world. The bishop builds material structures and a spiritual climate favorable to welcome young people. Cardinal Stanisław Dziwisz, the Archbishop of Krakow at that time, presided at the WYD Krakow 2016 Opening Mass on Tuesday 26 July. For the assembly, he was also an icon of St. John Paul II. The Archbishop was always present with St. John Paul II in his lifetime so whenever he appears today, he constantly brings to life the presence of the Holy Pope.

Preparation for the Mass was similar to the great gathering of the People of God, assembled at this symbolic place, called Błonia in Krakow. Hundreds of thousands of pilgrims were coming from the city for hours, often singing, despite a security checks and unfavorable weather. The introduction of the cross and the icon of the Mother of God, the signs accompanying WYD, was a meaningful moment. Carried by groups of young people in distinctive T-shirts and singing hymns of WYD recalled the history of those days which were held in Krakow for the thirty-first time. The relics of St. John Paul II and St. Sister Faustina, patrons of WYD Krakow 2016, were also introduced so that they accompany all the events of these days. The "Fire of Mercy", which has been burning continuously in the Sanctuary of Divine Mercy since 2003, was also solemnly introduced. It recalled the mystical experience of St. Sister Faustina, described in The Diary on January $29,1935 .^{5}$

The community gathered in Błonia was truly international. It was accompanied by about 400 bishops from different countries and several thousand priests. Seeing this great and diverse assembly, in his homily, Cardinal Dziwisz referred to the Pentecost, where people were gathered "from every nation under heaven" (Acts 2:5). ${ }^{6}$ Mass was also attended by a delegation

5 Cfr. St. S. Faustina, The Diary, n. 370.

6 Card. S. Dziwisz, Homily - Blonia (26 July 2016), in: Pielgrzymka odwagi i nadziei. Franciszek w Polsce z młodzieżą świata - ŚDM Kraków 2016, red. J. Sosnowska, Kraków 2016, p. 36. 
216 of the Orthodox Patriarchate of Moscow with the metropolitan Isidor of Smolensk and Roslavl. It was a true breeze of the Holy Spirit. All were gathered by St. John Paul II, who was referred to in the liturgical texts. Together with St. Sister Faustina, he pointed out the Mystery of the Divine Mercy, of which he was a zealous herald. The preacher emphasized this in reference to the words of the prophet Isaiah (Isaiah 52:7). ${ }^{7}$ And to the youth, referring to the Gospel about Peter's confession (Jn 21:15-17), he pointed that Christ also today, on the banks of the Vistula, raises demanding questions.

The liturgical assembly, full of enthusiasm, but also full of concentration and prayer, did not resemble festivals or concerts. It was a church which prayed by singing, participated in the celebration, kept silence, and shared joy. And when the time came, about 2000 ministers of Eucharist distributed 220,000 Holy Communion to the participants. The basic words of the liturgy resounded in Latin, but there were also many other languages, even Old Church Slavic language in the singing of the Gospel.

\subsection{The ceremony of the papal welcome}

Another important moment of WYD was the welcoming of the Holy Father by pilgrims. It always involved great enthusiasm and became a joyful feast. The Holy Father was welcomed here by the inhabitants of the Royal City of Krakow, and above all, the great international and colorful community of young people from all the continents. They expressed their joys well in their singing and dancing.

However, the Holy Father's arrival to the faithful, who were gathered there, also had a liturgical dimension. The appearance of the bishop in the community shows a full sign of the Church and the bishop is the visible sign of Christ the Head. ${ }^{8}$ Only a community of the faithful, persevering with their shepherd, is truly and fully the Church. ${ }^{9}$ The Holy

\footnotetext{
7 Card. S. Dziwisz, Homily - Blonia (26 July 2016), in: Pielgrzymka odwagi i nadziei. Franciszek w Polsce z młodzieżą świata - ŚDM Kraków 2016, red. J. Sosnowska, Kraków 2016, p. 38.

$8 \mathrm{Cfr}$. The General Instruction of the Roman Missal, 118.

9 Cfr. Conc. Vatican II, Constitution Lumen Gentium, 26; Caeremoniale Episcoporum, Typis Polyglottis Vaticanis 1985, n. 18.
} 
Father's arrival was an important moment in the building of this uni-

ty in the Church. The Church gathered in Błonia, was really community, what was seen and heard.

The theme of mercy united the participants around the Holy Father. Each continent presented saints who performed works of mercy there. There was Saint Vincent de Paule ( $† 1660)$ from Europe, Blessed Mother Teresa of Calcutta $(\dagger 1997)$ represented by Asians, from Australia and Oceania they brought Saint Maria MacKillop ( $† 1909)$, a caretaker of abandoned children and the first saint from this continent. Saint Josephine Bakhita (†1947), a slave and a saint from Sudan, represented Africa. The great missionary, Saint Fr. Damian de Veuster of Molokai ( $\dagger 1889)$, an apostle of the lepers, was recalled by the pilgrims from North America. Blessed Irmã Dulce ( $† 1992)$, who for 50 years took loving care of the homeless and beggars in El Salvador, became a sign of young people from Latin America. In this way, the true richness of the community of the Church was shown.

After a brief celebration, the Gospel of Jesus' visit in Bethany, at the house of Lazarus, Martha and Mary, was read (Luke 10:38-42). The reading began with an interesting sign. The gospel was carried by a chain of saints from different eras, so that the Gospel could reach us also. A young Roman martyr from the 4th century, Saint Agnes ( $† 304)$ and a young Polish Queen, Saint Jadwiga ( $† 1399)$ appeared in the chain. There were young Saint Dominik Savio ( $† 1857)$ and a teenage martyr from Uganda, Saint Kizito ( $\dagger 1886)$, burned at the stake almost immediately after his baptism. There was also Saint Therese of the Child Jesus ( $† 1897)$, who was loved by many, as well as a wonderful young man, Blessed Pier Giorgio Frassatti $(\dagger 1925)$ and a thirteen-year-old martyr from Italy, Saint Maria Goretti (†1902). There was Blessed Joseph Sánchez del Río (†1928), a thirteen-year-old hero from the time of persecution in Mexico and new Blessed Franciscan martyrs, Zbigniew Strzałkowski and Michał Tomaszek.

The Holy Father in his homily, emphasized the importance in the life of every Christian, of the ability to kindly accept Christ and to listen to him, as it was in Bethany. That is when we become truly his disciples. The 
218 following days created such an opportunity for the pilgrims and the Holy Father that it was even called "The Adventure of Mercy". ${ }^{10}$

\subsection{The Way of the Cross}

Friday, July 29, was, essentially, the day of the celebration of the Way of the Cross in Blonia, on Krakow. This has been included in WYD from the beginning, since it refers to the redemption of man by Christ. In Krakow, we experienced it as an inspiration to undertake the works of mercy. This meditation is not limited to our compassion for the Savior, but continually encourages an active imitation of Him. On this day, the young pilgrims were also offered a voluntary act of renunciation as a sign of accompanying Christ on the path of His renunciation.

The WYD Cross was carried by representatives of groups performing various charity works in their communities, as well as by some disabled people. At each station, the reflection on our Lord's passion pointed to a concrete work of mercy ${ }^{11}$ which the faithful can undertake on a daily basis. A realization of such works in practice and in a concrete environment was presented in a short film, reflecting on the Passion of the Lord as a way to follow Christ. ${ }^{12}$ This was emphasized by the Pope in his reflection at the conclusion of the service with encouragement to undertake a work of mercy in our environment. We cannot go away sad, but full of zeal to overcome evil. ${ }^{13}$

10 Pope Francis, Address Blonia (28 July 2016), http://w2.vatican.va/content/francesco/ en/speeches/2016/july/documents/papa-francesco_20160728_polonia-accoglienza-giovani.html (15.07.2017).

11 Works of Mercy are an old Christian practice, indicating to the faithful real ways to pursue the road of Christian life. These are the acts of charity. They list the seven works of mercy carried out by noticing the temporal needs of one's neighbor (body) and the seven works of mercy carried out on the moral level (soul). Cfr. Catechism of the Catholic Church, 2447.

12 For example, one can recall that the meditation of the first station shows Jesus as a homeless man, so the film presented the work of the brothers of St. Albert in the kitchen for the homeless, and they too were shown carrying the cross in the celebration.

13 Cfr. Pope Francis, Address at the Conclusion of Way of the Cross (29 July 2016), http:// w2.vatican.va/content/francesco/en/speeches/2016/july/documents/papa-francesco_20160729_polonia-via-crucis.html (15.07.2017). 
The celebration was held in a climate of absolute concentration and prayer. Seeing young people praying kneeling down in mud or stones was very emotional. The atmosphere of prayer was complemented by images with well-chosen multimedia effects and touching music.

\subsection{The Vigil}

The Vigil with the Holy Father on Saturday evening also belongs to the oldest components of the whole WYD. A vigil is a prayerful preparation for an important event in the life of the Church. It has always been an important element in the Christian tradition from its very beginning. ${ }^{14}$ This time it took place in the fields between Krakow and Wieliczka on 30 July. It was the only place where the millions of participants were able to reach, gather, stay and peacefully leave on Sunday. In preparing this place, the organizers began to call it Campus Misericordiae - the Field of Mercy, and they built a house there to help people who suffer in various ways. This is a testimony to the spirit in which this great event of the Year of Mercy was prepared.

The first meaningful sign of this evening, after the Pope's arrival, was his entering through the Gate of Mercy along with a group of young people from different continents. We were in the middle of the Holy Year. Our Gate was unique. It was not a door leading into the interior of a church building, but it led to the midst of the crowds. It reminded us of Christ, Who introduced us to the Church community through baptism and, therefore, here all formed a true Church.

The idea of the vigil at Campus Misericordiae was rooted in the prayer that was being said in preparation for these Days, and especially these words: "Teach us how to convey the faith to those in doubt, hope to those who are discouraged, love to those who feel indifferent, forgiveness to those who have done wrong and joy to those who are unhappy. Allow the spark of merciful love that you have enkindled within us to become a fire that can transform hearts and renew the face of the earth." From this

14 Cfr. Col 4:2; 1 Th 5:9-11;2 Co 11:27; Mt 26:41; Lk 21:36. Community of the Church: Acts 2:42. Paul and Silas Actc 16:25. 
perspective, topics of contemporary social problems were addressed and the light to solve them sought. They were presented through short performances and testimonies, and were focused on a lack of a sense of life in the youths' environments, the problem of war, suffering and injustice, the addictions of today's people, the need for forgiveness, and the need to share genuine joy with those who are sad. A solution for these problems was sought in the life and teachings of the two main guides, St. John Paul II and St. Sister Faustina. Pope Francis was also asked about it. He talked about how today's world needs the youth, not sitting on the couch, but "in running shoes". ${ }^{15}$ They all unanimously pointed to the necessity of approaching the Merciful Christ. The beautiful completion of this message was the symbolic creation of the image of Divine Mercy in front of those gathered, by St. Faustina, whose role was played by a young actress.

The central moment of this reflection and prayer was the brief adoration of the Blessed Sacrament. This moment was something special. On the huge field, millions of people were kneeling in silence, holding lit candles in their hands. An extraordinary dialogue with God, which was held in the rhythm of the sung Divine Mercy Chaplet, ended with a sacramental blessing. The singing of the Jasna Góra Appeal recalled the presence of the Mother of God. Of course, it was sung in the Latin version, Maria Regina Mundi, which we remembered from the World Youth Days in Częstochowa in 1991.

The specially prepared altar setting, created by the artist Mariusz Drapikowski, ${ }^{16}$ was used to display the Blessed Sacrament. The most precious part of this exquisite composition was the monstrance, adorned with magnificent, even enormous pieces of amber. This work of art, used for prayer at Campus Misericordiae in Krakow, was then transported to martyred Africa, to the Marian shrine in Kibeho (Rwanda). With this altar, the experience of the youth's faith at Campus Misericordiae was, in a way, carried to Africa where it is needed so much.

15 Pope Francis. Address during the Vigil (30 July 2016), http://w2.vatican.va/content/francesco/en/speeches/2016/july/documents/papa-francesco_20160730_polonia-veglia-giovani.html (15.07.2017).

16 Mr Drapikowski has made already few such works, which are in different parts of the world, especially in places touched by sufferings and wars. 
The prayer in this evening was unique. The elements of street art, magnificent music, a multitude of languages and reflective silence at the appropriate moments allowed one to experience the scent of the Holy Spirit. The gaze of the Merciful Jesus, from the decorations at the altar, accompanied the pilgrims constantly, allowing them to calmly fall asleep and to wake up with the conviction that our Lord looks upon us with love.

\subsection{The sending forth of the pilgrims}

Although Sunday Mass is basically the close of WYD, it has, from the very beginning, been treated as a moment of sending forth the young people, in the pattern of the sending forth of the Apostles by Jesus. Therefore, we do not talk about the ending of WYD.

The liturgical texts of the celebration summarized the spiritual experiences of these Days. The great liturgical assembly, characterized by the presence of people from different cultures and nations, under the guidance of Holy Father Francis, is a visible sign of the universal Church. It is the work of Divine Mercy and, gathering constantly around the Savior, gives witness to Him in the world. Sunday is a special day, the "first day of the week", the day of sending forth the Apostles to share peace and reconciliation (Jn 20: 19-23).

The Gospel recalled the scene of Christ's encounter with Zacchaeus. When the Savior looked at him, he accepted Him into his house and everything in his life changed. He became a man joyfully carrying out works of mercy. In his homily, the Holy Father addressed the theme of Zacchaeus, and indicated the obstacles which hindered his coming to Jesus. The Pope pointed out how much we need to remember our value in God's eyes and the attractiveness of Jesus for everyone. ${ }^{17}$ There is a need to see Christ's gaze and to learn to accept Him in our life. Jesus' gaze constantly accompanied the gathered people through the decoration at the altar. Holy Communion, which was accepted by about half a million participants, was the reception of Jesus in the home of our hearts.

17 Pope Francis, Homily in the Sending Mass (31 July 2016), http://w2.vatican.va/content/ francesco/en/homilies/2016/documents/papa-francesco_20160731_omelia-polonia-gmg.html (15.07.2017). 
It is also worth noting that on Sunday, the Gospel was again proclaimed solemnly in the Roman and the Byzantine Slavic rites. For many centuries, Poland has been a place of combining these two traditions. Therefore, it could not be otherwise on the day when the universal Church appeared so splendidly in our land. There was also a large number of the faithful of the Byzantine rite, especially Greek Catholics and Armenians, at our ceremonies.

WYD Krakow 2016 was held on the 1050th anniversary of the baptism of Poland. The grace of mercy touched our nation then. We shared this joy with all the participants of our events, coming from many countries. During the profession of faith, we tried to put on a white scarf, a symbol of the white baptismal garment. The sign was modest, but it allowed us to see how the grace of Christ made us similar to each other despite our diversity. Holy baptism has introduced our nation to a great family of Christian nations.

The whole Sunday celebration had the character of a sending forth of the youth. At the end of Mass, the Holy Father gave oil lamps with the Fire of Mercy, which had accompanied all the celebrations, to representatives from the six continents. It was a visible sign of the fire which probably burned in the hearts of the participants and which they were to bring into their environments. The final act of the sending forth was also the announcement of the next WYD in Panama in 2019.

\section{The characteristics of WYD}

Having experienced these wonderful days of grace in Krakow, we cannot leave them only to history. God gave us the opportunity to experience a special time. Our reflection on this gift is undoubtedly an expression of our gratitude to Him. It is worth trying to make some conclusions which will help us to draw on the blessed fruit of WYD.

\subsection{Enthusiasm and the youth's faith}

Indeed, there is something characteristic in the joy of young people who meet each other and meet Christ during WYD. However, anyone who 
looked closely at this joy, who embraced the enthusiasm of young participants of WYD, can easily see the its depth. St. John Paul II knew it, linking the youth meetings with the Palm Sunday celebrations. The Gospels then tell us about the enthusiasm of young people who accompanied Jesus on His way to Jerusalem. ${ }^{18}$ It has been done for centuries in the liturgy of the Church in the procession with palms and in the well-known singing: Pueri Hebreorum. The Holy Pope also saw it among the young today. "Young people surround Jesus Christ in the Palm Sunday liturgy, expressing their enthusiasm which He awakes in the midst of ever-renewing generations". ${ }^{19}$ Young people are supposed to pass it on to the modern world. It is born out of a young person's encounter with Christ during the liturgy. Therefore, liturgical celebrations have always been at the center of WYD and around them, all the joyful but deepened experience of faith is created. Pope Benedict described the enthusiasm, born out of the young man's encounter with Christ, as an important remedy for today's society, which experiences a kind of faith fatigue. Young people, enamoured with Christ, show a rejuvenated way of being a Christian today. ${ }^{20}$ It needs deepening, but the delight in Christ is something very important, not only at the beginning of the path of faith. The joy arising from the experience of faith transforms these Days into a true feast of faith, of great importance to both believers and non-believers. Everyone who was in Krakow then, could personally experience a climate full of joy and enthusiasm of the young people, and their divine peace at the same time.

\subsection{The role of voluntary service}

As the WYD structures grew, more and more hands were needed to prepare the entire organization. A number of volunteers, who spared no time and service and, above all, their heart for this work, also began to grow.

18 Cfr. Mt 21:9-15.

19 Pope John Paul II, Homily in Palm Sunday (15 April 1984) 3, http://w2.vatican.va/content/john-paul-ii/it/homilies/1984/documents/hf_jp-ii_hom_19840415_palme.html (15.07.2017).

20 Cfr. Pope Benedict XVI, Address to the Roman Curia (22 December 2011), "Acta Apostolicae Sedis" 104/1 (2012) 36. 
224 They were able to spend weeks and months of their lives in order to prepare this event. They did not expect payment, but the greatest reward for them was the discovery that doing something for others and being for others is just beautiful. Pope Benedict noticed this value during a meeting with volunteers and talked about it at a meeting with the Roman Curia in 2011. ${ }^{21}$

The breath of the Spirit in the volunteers' service was felt also in Krakow. Many activities required an involvement of professionals, but the volunteers could perfectly meet everyday needs from the beginning of the preparations. They were indispensable in their care for spiritual preparation, for creating a climate characteristic of WYD. Dozens of volunteers were involved in the pilgrimage of symbols (cross and icon of the Mother of God) throughout Poland. They led catechesis at schools, created mobile applications which encouraged prayer. It is worth mentioning the application "Tolle et lege", which encourages the reading of the Word of God and enables sharing the reflection on it. Great initiatives under the theme of "Touch Mercy" as well as "L4", involving the sick to offer their prayers for WYD. The "home hospital" campaign united young people to pray for the moral renewal of Krakow. They organized a prayer relay for WYD and showed the beauty of the Sacrament of Reconciliation in the "Heart 2.0" program, which was in operation since 2014. Under the influence of Pope Francis's message, the volunteers created the program "Be more than have", which recalled saints, especially those from Krakow, as models for fulfilling the Beatitudes concerning evangelical poverty, chastity and mercy. One must recall their friendly presence in places of prayer, catecheses, on the streets, distributing food, wherever a helpful hand was needed. Therefore, Pope Francis, during the meeting at Tauron-Arena, when he thanked them for their commitment, sacrifice and dedication, added: "I would like to thank you for the hours you spent on prayer, because I know that these Days were carved with the greatness of your work and prayer". ${ }^{22}$

21 Cfr. Pope Benedict XVI, Address to the Roman Curia..., op. cit., 37.

22 Pope Francis, Address to WYD Volunteers (31 July 2016), http://w2.vatican.va/content/ francesco/en/speeches/2016/july/documents/papa-francesco_20160731_polonia-volontari-gmg.html (15.07.2017). 
Eucharistic adoration also accompanies WYD almost from the beginning. It creates an important form of spirituality. The moments of deep silence of Christ present in the Blessed Sacrament are a meaningful profession of faith. In Pope Benedict's interpretation, it resembles the confession of St. Thomas: "my Lord and my God!" Then, it is the experience of a true presence of the Risen Christ. ${ }^{23}$ A short adoration took place during the vigil, but it took place also in churches after catecheses, and at night, lasting the whole night in the Eucharistic tents at Campus Misericordiae. It was not an episode, but an important element of those great days which grows out of the deep needs of a person seeking Christ, the need to be close.

\subsection{The meaning of the sacrament of reconciliation}

The possibility of confession has always existed during WYD, since 1984. However, only since 2000, at the explicit request of the young, the place of confession, with hundreds of confessionals, calling them in time the "Park of Reconciliation," began to be organized. Again, let us recall Pope Benedict's reflection. Having a sense of sin, though often drowned out, a man tends to close up and easily surrender to the logic of evil. Awareness of the outstretched hand of the Savior and humbly appealing to Him to enable us to revive in our souls the reverse tendency, that is opening up and looking for good. A positive power of the Creator encourages people to further development. ${ }^{24}$ Reflecting on the mystery of the Divine Mercy, it was necessary to create the proper conditions for confession. A meadow between the Divine Mercy and St. John Paul II Shrines, where hundreds of white confessionals were placed were perfectly suited. Hundreds of confessors served there and Pope Francis also joined them. Confession took place everywhere, after the catecheses, while waiting for central events, while walking from one place to another. It was the time of mercy, the time of reconciliation and the renewal of humankind.

23 Pope Benedict XVI, Address to the Roman Curia..., op. cit., 38.

24 Pope Benedict XVI, Address to the Roman Curia..., op. cit., 38. 


\subsection{The feast of the Church}

It is estimated that about two to two and a half million pilgrims arrived at Campus Misericordiae. Among them, there were about twenty thousand priests, over eight hundred bishops, and about four thousand Eucharistic ministers who distributed Holy Communion. When there are no divisions or separation among such variety of languages, customs and cultures; the obvious work of Christ must be seen in this. Only He can bring people together and create a community giving them the gift of the Holy Spirit. It is no longer a gathered crowd, but a community of the Church, the Catholic, so universal, Church. Let us recall Pope Benedict once again. It is in the liturgy that he saw the moment of transformation of the assembly into the praying Church. "The liturgy is a kind of a heartland and it unites us in a great family. The fact that all human beings are brothers and sisters becomes not just an idea here but a real common experience which brings joy". ${ }^{25}$ The sign of the Church is also complemented by the presence of the Holy Father, its visible head.

The Sunday liturgy spoke of the Church as a gift of the Divine Mercy for the world, what we could personally experience during these Days. The richness of the Church is the experience of the faith of the young and the old. According to St. John Paul II's vision, youth not only have to listen to the Church, but they have something to say to the Church. "This bilateral dialogue, which should be carried out in a climate of warmth, openness and courage, will facilitate the meeting of generations and the exchange between them, and for the Church and society, it will be a source of wealth and youthfulness". ${ }^{26}$ WYD Krakow 2016 experience was undoubtedly an enrichment for the whole Church, the young and the old, Poles and pilgrims, clergy and the faithful.

\footnotetext{
25 Pope Benedict XVI, Address to the Roman Curia..., op. cit., 38.

26 Pope John II, Apostolic Exhortation Christifideles Laici, on the Vocation and the Mission of the lay Faithful in the Church and in the World (30 December 1988) 46, "Acta Apostolicae Sedis" 81 (1989), p. 482.
} 


\section{The message of the Divine Mercy}

The subject of each WYD is designated by the Holy Father. He also designates a topic of work for young people during the years of preparation. In recent years, the Pope has suggested to the young to reflect on the consecutive Beatitudes from the Sermon on the Mount (Mt 5:3-12). However, looking at the order of the topics (Mt 5:3-5:8-5:7), it can be concluded that he had already planned the theme of charity for WYD in Krakow. No wonder the spark of this message came out from here. The motto "Blessed are the merciful, for they shall obtain mercy" (Mt 5:7) clearly indicates an attitude and act of mercy. It does not restrict the message only to some act of piety. For Pope Francis, this is the mission of the faithful, as he emphasized in the WYD Message. This time is "a time for the Church to rediscover the meaning of the mission entrusted to her by the Lord on the day of Easter: to be a sign and an instrument of the Father's mercy". ${ }^{27}$ The Holy Father's Message called for action, like the Father showing mercy to man. Such an attitude brings much joy in life. Therefore, the liturgy of the central events had to take into account the Pope's indications mentioned above.

The Pope's view of the mystery of Divine Mercy was certainly presented by the two main WYD Patron Saints, St. Sister Faustina and St. John Paul II. Paintings of them were visible in the decorations on the podium on Błonia and at Campus Misericordiae, and their symbolic images adorned the streets of Krakow. Their relics, set next to the WYD symbols, formed together one message to the participants. Their attitudes and teachings, seeking for effective action against evil, including anonymity, indifference, suffering and a lack of joy in today's world, were recalled during Saturday's vigil. Daily praying of the Divine Mercy Chaplet as well as contact with the Diary were also helpful for the pilgrims.

A dynamic understanding of the Divine Mercy message could also be seen in the Holy Father's constant encouragement to practice the works of

27 Pope Francis, Message for the Thirty-first World Youth day 2016 (15.08.2015) 1, http:// w2.vatican.va/content/francesco/en/messages/youth/documents/papa-francesco_20150815_messaggio-giovani_2016.html (15.07.2017). 
228 mercy. Mercy cannot be understood as a symptom of sentimentality, but as a life program in deeds. ${ }^{28}$ The best opportunity to take up this topic was the reflection on the Way of the Cross, where even the number of stations corresponded with the number of works of mercy. Thereby, the Way of the Cross was not limited only to historical memories or sentimental emotions. ${ }^{29}$ The reflections, based on the Scriptures, and the presence of people doing works of mercy in different sectors, opened to the participants this perspective of Christian commitment.

Another aspect of the contemplation of the Countenance of Merciful Jesus, which appeared during the liturgical celebrations, is to be noted. It is an experience of the entire Church community. The characteristic feature of the praying community is the mutual sharing of the spiritual wealth which is faith, hope and love. The potential of the spiritual experience in the liturgy is so great that it helps to complement the personal shortcomings of the individual participants. The successor of St. Peter, the Patron Saints who roused the idea of Mercy in the Church, as well as the other saints mentioned on Tuesday and Thursday, were present in this community. Finally, each celebration in the Church also ends with the message "Go...". Therefore, the experience of those Days for young people in the church community has to lead them into ministry, which is so special to the Merciful Jesus. The Church leads young people to work on the paths of Mercy.

\section{Summary}

When, in 1984, in St. John Paul II's prophetic vision, a plan for the youth meetings with Christ on Palm Sunday was being born, many doubted the effectiveness of such a pastoral initiative. Today, having experienced 31

28 Pope Francis, Message for the Thirty-first World Youth day 2016, op. cit.

29 In this mood, the Works of Mercy was adapted to the Way of the Holy Cross in Cracow: I - To shelter the homeless; II - To feed the hungry; III - To admonish the sinners; IV To comfort the afflicted; $\mathrm{V}$ - To visit the sick; $\mathrm{VI}$ - To visit the imprisoned, or ransom the captive; VII - To forgive offenses; VIII - To instruct the ignorant; IX - To counsel the doubtful; $\mathrm{X}$ - To clothe the naked; XI - To bear patiently those who wrong us; XII To give water to the thirsty; XIII - To pray for the living and the dead; XIV - To bury the dead. 
WYDs, we can see the blessed fruit of this initiative in the Church and so-

ciety. Thanks to these meetings of youth with Christ in the Church, people grow closer to one another and the potential for mutual kindness is triggered. The living faith in old societies receives a boost of youthfulness and revival. Voluntary service, the selfless engagement of young people for the sake of goodness, in contrast to the ruthless principles in many areas of social life, develops. The joy and enthusiasm of the youth build good relationships between peoples. These great values were experienced when a man, like Zacchaeus, meets Christ. And this happens in a well-understood and suitably prepared liturgical celebration.

\section{Bibliography}

Second Vatican Council, Constitution Sacrosanctum Concilium (4 December 1963), "Acta Apostolicae Sedis" 56 (1964), pp. 97-134.

Second Vatican Council, Constitution Lumen Gentium (21 November 1964), "Acta Apostolicae Sedis" 57 (1965), pp. 5-75.

Catechism of the Catholic Church (1992).

Caeremoniale Episcoporum, Typis Polyglottis Vaticanis 1985.

The General Instruction of the Roman Missal (2002).

Pielgrzymka odwagi i nadziei. Franciszek w Polsce z młodzieżą świata - ŚDM Kraków 2016, red. J. Sosnowska, Kraków 2016.

Pope John Paul II, Homily in Palm Sunday (15 April 1984) 3, http://w2.vatican.va/ content/john-paul-ii/it/homilies/1984/documents/hf_jp-ii_hom_19840415_ palme.html (15.07.2017).

Pope John Paul II, Address to Roman Curia (20 December 1985) 3, "Acta Apostolicae Sedis" 78 (1986), p. 623.

Pope John II, Apostolic Exhortation Christifideles Laici, on the Vocation and the Mission of the lay Faithful in the Church and in the World (30 December 1988) 46, "Acta Apostolicae Sedis" 81 (1989), p. 482.

Pope Benedict XVI, Address to the Roman Curia (22 December 2011), "Acta Apostolicae Sedis" 104/1 (2012), pp. 36-38.

Pope Francis, Message for the Thirty-first World Youth day 2016 (15.08.2015) 1, http:// w2.vatican.va/content/francesco/en/messages/youth/documents/papa-francesco_20150815_messaggio-giovani_2016.html (15.07.2017).

Pope Francis, Address Blonia (28 July 2016), http://w2.vatican.va/content/francesco/en/speeches/2016/july/documents/papa-francesco_20160728_polonia-accoglienza-giovani.html (15.07.2017). 
Pope Francis, Address at the Conclusion of Way of the Cross (29 July 2016), http://w2. vatican.va/content/francesco/en/speeches/2016/july/documents/papa-francesco_20160729_polonia-via-crucis.html (15.07.2017).

Pope Francis. during the Vigil (30 July 2016), http://w2.vatican.va/content/francesco/en/speeches/2016/july/documents/papa-francesco_20160730_polonia-veglia-giovani.html (15.07.2017).

Pope Francis, Homily in the Sending Mass (31 July 2016), http://w2.vatican.va/content/francesco/en/homilies/2016/documents/papa-francesco_20160731_omelia-polonia-gmg.html (15.07.2017).

Pope Francis, Address to WYD Volunteers (31 July 2016), http://w2.vatican.va/ content/francesco/en/speeches/2016/july/documents/papa-francesco_20160731_polonia-volontari-gmg.html (15.07.2017).

St. S. Faustina, The Diary. 